\title{
Quality and Glycaemic Index of Wheat Bread with Different Shares of Chickpea Flour ${ }^{\dagger}$
}

\author{
Gabriela Zięć ${ }^{1, *}$, Halina Gambuś ${ }^{1}$, Marcin Lukasiewicz ${ }^{2}$, Florian Gambuś ${ }^{3}$ and Jagoda Karkoszka ${ }^{1}$ \\ 1 Department of Carbohydrate Technology, University of Agriculture in Krakow, Balicka 122, \\ 30-149 Kraków, Poland; halina.gambus@urk.edu.pl (H.G.); jagusia.karkoszka@gmail.com (J.K.) \\ 2 Department of Engineering and Machinery in Food Industry, University of Agriculture in Krakow, \\ 30-149 Kraków, Poland; marcin.lukasiewicz@urk.edu.pl \\ 3 Department of Agricultural and Environmental Chemistry, University of Agriculture in Krakow, \\ 30-149 Kraków, Poland; florian.gambus@urk.edu.pl \\ * Correspondence: gabriela.ziec@urk.edu.pl; Tel./Fax: +48-12-6624747 \\ + Presented at the 1st International Electronic Conference on Food Science and Functional Foods, \\ 10-25 November 2020; Available online: https://foods_2020.sciforum.net/.
}

Citation: Zięć, G.; Gambuś, H.; Lukasiewicz, M.; Gambuś, F.;

Karkoszka, J. Quality and Glycaemic Index of Wheat Bread with Different Shares of Chickpea Flour.

Proceedings 2021, 70, 89.

https://doi.org/10.3390/

foods_2020-07651

Published: 9 November 2020

Publisher's Note: MDPI stays neutral with regard to jurisdictional claims in published maps and institutional affiliations.

Copyright: $(2020$ by the authors. Licensee MDPI, Basel, Switzerland. This article is an open access article distributed under the terms and conditions of the Creative Commons Attribution (CC BY) license (http://creativecommons.org/licenses/by/4.0/).

\begin{abstract}
The aim of the work was to evaluate the quality, i.e., to determine the volume, calculate the total baking loss and yield, and also perform the organoleptic evaluation, of wheat bread with chickpea flour. Moreover, the purpose of the work was also the evaluation of the staling change process in bread; determination of the contents of chemical components, including protein, fat, ash and fibre; determination of the contents of micro and macroelements; and determination of the glycaemic index in vitro. The research material was wheat bread and wheat bread supplemented with different proportions of chickpea flour $(10 \%, 15 \%$ and $30 \%)$. On the basis of the conducted research, it was found that the addition of chickpea flour significantly influenced all the quality characteristics, for example, by reducing the volumes of the loaves. In the organoleptic evaluation, the bread obtained quality class 1 , with the exception of the bread with $30 \%$ chickpea flour. The chickpeawheat breads, on the day of baking, were characterized by lower moisture than the wheat bread, and this trend continued throughout the storage period. In terms of nutrients and micro- and macroelements, the more the share of chickpea flour, the higher their contents. The values of the glycaemic index were similar among the breads supplemented with different proportions of chickpea flour, and for wheat bread, it was the biggest. Based on the study, it can be stated that bread with $10 \%$ and $15 \%$ shares of chickpea flour had quality similar to that of wheat bread, so chickpea flour can be recommended as an addition in order to enrich wheat bread.
\end{abstract}

Keywords: quality; chickpea flour; glycaemic index

\section{Introduction}

A lack of a balanced diet is an etiological factor in metabolic disorders and largely contributes to the development of diseases called the common term chronic noncommunicable diseases, colloquially known in the past as "civilization diseases". Among them, there are diabetes, atherosclerosis, obesity and cancer. In order to prevent these diseases, various types of pro-health products are promoted on the market. The grain and milling industry is also expanding the range of its activities by introducing products enriched with the products of various nonbread crops, including legume seed products [1-3]. Chickpea seed flour is one of the possible raw materials used in supplementing wheat bread. It is characterized by a high content of proteins that, in their composition, contain almost all the necessary amino acids; macro- and microelements (phosphorus, potassium, iron and magnesium); and fibre, as well as B vitamins. In addition, the seeds show healing 
properties. Hence, it seems justified to use this flour as a raw material in baking white bread in order to enrich it with nutrients [1-4].

\section{Materials and Methods}

The research material was wheat bread and wheat bread supplemented with different proportions of chickpea flour $(10 \%, 15 \%$ and $30 \%)$.

The recipes for the wheat bread and wheat bread supplemented with different proportions of chickpea flour $(10 \%, 15 \%$ and $30 \%)$ are shown in Table 1.

Table 1. Recipes for wheat flour bread and wheat bread supplemented with different proportions of chickpea flour $(10 \%, 15 \%$ and $30 \%)$.

\begin{tabular}{cccccc}
\hline Kind of Bread & Wheat Flour $(\mathrm{g})$ & Chickpea Flour $(\mathrm{g})$ & Salt $(\mathrm{g})$ & Yeast $(\mathrm{g})$ & Water $(\mathrm{mL})$ \\
\hline CHP $^{*}$ & 1000 & - & 20 & 30 & 665 \\
CHP10 & 900 & 100 & 20 & 30 & 665 \\
CHP15 & 850 & 150 & 20 & 30 & 665 \\
CHP30 & 700 & 300 & 20 & 30 & 665 \\
\hline
\end{tabular}

${ }^{*} \mathrm{CHP}$ - wheat bread; CHP10 - wheat bread with 10\% share of chickpea flour; CHP15 - wheat bread with $15 \%$ share of chickpea flour; CHP30 - wheat bread with 30\% share of chickpea flour.

The dough was prepared using a straight method with a laboratory spiral mixer, a Diosna type SP 12 (Dierks \& Söhne, Osnabrück, Germany). Baking was performed at $230^{\circ} \mathrm{C}$ for $30 \mathrm{~min}$, in an electric oven, a MIWE CO 2 P608. Six loaves were baked for each batch. The loaves were cooled for $2 \mathrm{~h}$ and weighed, and their volumes were determined in a laser volume meter, a Volscan Profiler. Organoleptic assessment was performed according to PNA74108:1996 [5]. The chemical composition of the bread was determined according to the methods of AOAC (2006), including the dry mass (met. 925.10), total protein (met. 950.36), total dietary fibre (including soluble and insoluble fractions-met. 935.38), raw fat (met. 930.05), total ash (met. 930.05) and micro- and macroelements (modified methods 985.01) [6].

The glycaemic index in vitro of the tested bread was determined according to Goni et al. [7], with the use of enzyme solutions: pancreatic $\alpha$-amylase (P-7545, Sigma-Aldrich, St. Louis, MO, USA), amyloglucosidase $(3300 \mathrm{U} / \mathrm{mL}$, Megazyme International, Ireland Ltd., Bray, Ireland) and invertases (I 4504, 300 U/mg; Sigma-Aldrich, St. Louis, MO, USA). Glucose levels were determined by colorimetry using a reagent containing the enzymes glucose oxidase and peroxidase (K-GLOX 09/12, Megazyme International, Ireland Ltd., Bray, Ireland).

\section{Statistical Evaluation}

All the results were subjected to one-way analysis of variance (ANOVA) using the software STATISTICA 10. The significance of the differences was analysed by the Duncan test at $\alpha=0.05$. The results are presented as mean and standard deviation (SD).

\section{Results and Discussion}

Chickpea seed flour seems to be a suitable raw material for baking bread due to its nutritional value, i.e., high protein content, with almost all the necessary amino acids, as well as high contents of macro- and microelements, fibre and vitamins, in addition to good emulsifying properties. Therefore, it seems justified to use this flour as a raw material in baking white bread in order to enrich it with nutrients. Hence, the aim of the study was to assess the quality of bread and the chemical composition, as well as the in vitro glycaemic index, with $10 \%, 15 \%$ and $30 \%$ flour from chickpeas. The results in Table 2 show the quality of the wheat bread and wheat-chickpea bread. 
Table 2. Evaluation of quality of baked breads following baking.

\begin{tabular}{|c|c|c|c|c|c|c|c|}
\hline \multirow{2}{*}{$\begin{array}{c}\text { Type of } \\
\text { Bread }\end{array}$} & \multirow{2}{*}{$\begin{array}{l}\text { Weight of Cold } \\
\text { Bread (g) }\end{array}$} & \multirow{2}{*}{$\begin{array}{l}\text { Volume } \\
\left(\mathrm{cm}^{3}\right)\end{array}$} & \multirow{2}{*}{$\begin{array}{c}\text { Bread Yield } \\
(\%)\end{array}$} & \multirow{2}{*}{$\begin{array}{c}\text { Total Baking Loss } \\
(\%)\end{array}$} & \multirow{2}{*}{$\begin{array}{c}\text { Crumb } \\
\text { Moisture (\%) }\end{array}$} & \multicolumn{2}{|c|}{ Points Assessment } \\
\hline & & & & & & Score & Quality Class \\
\hline $\mathrm{CHP}^{*}$ & $\begin{array}{c}220.44 \mathrm{a}^{* *} \\
\pm 2.67\end{array}$ & $\begin{array}{c}796.25 \mathrm{c} \\
\pm 1.12\end{array}$ & $\begin{array}{c}145.93 \mathrm{a} \\
\pm 0.43\end{array}$ & $\begin{array}{c}11.82 \mathrm{c} \\
\pm 0.67\end{array}$ & $\begin{array}{c}45.10 \mathrm{a} \\
\pm 0.50\end{array}$ & $\begin{array}{c}39 \mathrm{a} \\
\pm 0.00\end{array}$ & - \\
\hline CHPC10 & $\begin{array}{c}224.42 \mathrm{~b} \\
\pm 1.58\end{array}$ & $\begin{array}{c}691.82 \mathrm{~b} \\
\pm 1.14\end{array}$ & $\begin{array}{c}147.51 \mathrm{~b} \\
\pm 0.26\end{array}$ & $\begin{array}{l}10.06 \mathrm{~b} \\
\pm 0.57\end{array}$ & $\begin{array}{l}45.82 \mathrm{a} \\
\pm 0.45\end{array}$ & $\begin{array}{c}39 \mathrm{a} \\
\pm 0.41 \\
\end{array}$ & I \\
\hline CHPC15 & $\begin{array}{c}227.35 \mathrm{~b} \\
\pm 5.05\end{array}$ & $\begin{array}{c}600.54 \mathrm{a} \\
\pm 1.71 \\
\end{array}$ & $\begin{array}{c}148.55 \mathrm{~b} \\
\pm 0.12 \\
\end{array}$ & $\begin{array}{l}10.03 \mathrm{~b} \\
\pm 0.15\end{array}$ & $\begin{array}{l}45.80 \mathrm{a} \\
\pm 0.72\end{array}$ & $\begin{array}{c}39 \mathrm{a} \\
\pm 0.87 \\
\end{array}$ & I \\
\hline СНРС30 & $\begin{array}{c}227.35 \mathrm{~b} \\
\pm 5.05\end{array}$ & $\begin{array}{l}550.54 \mathrm{a} \\
\pm 11.71 \\
\end{array}$ & $\begin{array}{c}150.55 \mathrm{c} \\
\pm 0.12 \\
\end{array}$ & $\begin{array}{l}9.03 \mathrm{a} \\
\pm 0.15 \\
\end{array}$ & $\begin{array}{l}45.80 \mathrm{a} \\
\pm 0.72 \\
\end{array}$ & $\begin{array}{c}36 \mathrm{a} \\
\pm 0.12 \\
\end{array}$ & II \\
\hline
\end{tabular}

${ }^{*} \mathrm{CHP}$ - wheat bread; CHP10 - wheat bread with $10 \%$ share of chickpea flour; CHP15-wheat bread with $15 \%$ share of chickpea flour; CHP30 - wheat bread with $30 \%$ share of chickpea flour; ${ }^{* *}$ mean values in columns denoted by different letters differ statistically significantly at $p \leq 0.05$.

The increased water absorption of flour is a very important and desirable feature in the production of bread $[8,9]$. It has a large impact, resulting in greater efficiency in breadmaking and, as a result, a lower baking loss [9]. The yield of the breads with chickpea flour was higher than the value of this parameter that characterized the wheat bread, and thus, the baking loss of these breads was significantly lower compared to the standard (Table 2). The obtained results confirm the good quality of wheat-chickpea bread.

The effect of the addition of chickpea flour can also be seen when comparing the volumes and weights of the loaves. It was found that the greater the proportion of chickpea flour, the smaller the volumes and weights of the loaves. With regard to the wheat bread, one can also notice large differences between the volumes of the bread. For the bread with 30\% chickpea flour (CHPC30), this value is 30\% lower compared to that for the wheat bread (CHP). Moreover, there is an inverse relationship between the volume of the loaves and the amount of chickpea flour added. The volume of the wheat bread was higher, which is related to the fact that wheat flour contains gluten proteins, which are not found in chickpea flour. These proteins are responsible for the structure and porosity of the loaf.

The differences between the tested breads can be noticed not only in terms of their structural properties, such as weight or volume, but also in the colour of the crust or the crumb (Figure 1). The colour of the crust and the flesh of the bread depend, to a large extent, on the contents of pigments present in the flour. For this reason, the breads with chickpea flour were characterized by a darker colour than the wheat bread, and the individual wheat-chickpea breads showed differences in colour; the greater the addition of chickpea flour, the darker the colour. The darker colour of these breads depended on the pigments contained in the chickpea flour, such as riboflavin, which is responsible for the cream colour of the chickpea grain and, thus, also the flour [2]. The skin colour is also influenced by the products of many reactions known as nonenzymatic browning. These include the Maillard reaction, during which brown melanoids are produced; the caramelization of saccharides, the reactions of quinones with amines, reactions with metal ions, and the reaction of oxidized lipids with proteins. The speed of the nonenzymatic browning reaction increases in direct proportion to the temperature; it depends on the amount of water in the product and on the $\mathrm{pH}$ of the environment [10].

Replacing wheat flour with chickpea flour in the amounts of $10 \%, 15 \%$ and $30 \%$ increased the weight of the wheat-chickpea bread compared to wheat bread (Table 2). This was probably caused by greater water retention in the bread crumb, which is confirmed by the greater efficiency of this bread's production and, thus, lower baking loss (Table 2).

On the baking day, an organoleptic evaluation was also performed. The evaluation was carried out by a fifteen-person evaluation panel with proven sensory sensitivity. Only the bread with a $30 \%$ share of chickpea seed flour was rated worse and qualified for the 
second quality class (Table 2). The breads with chickpea flour were rated worse in terms of taste and aroma.

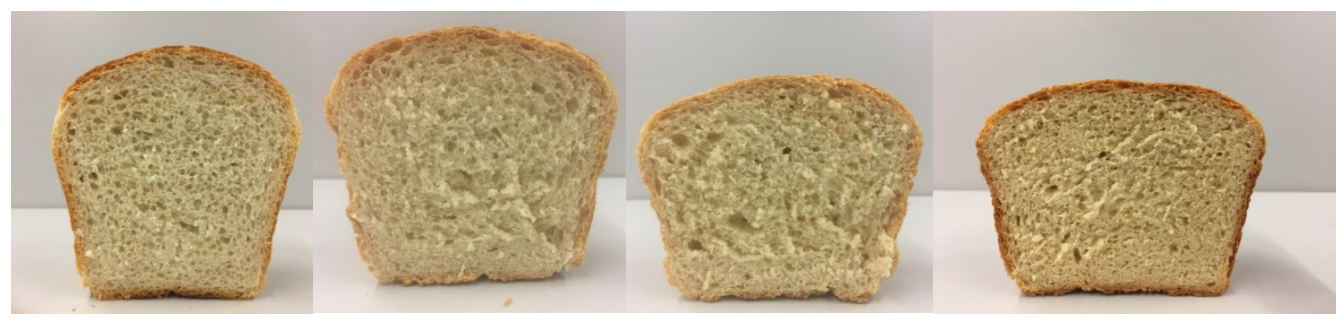

Figure 1. The external appearance of the bread: CHP, CHP10, CHP15 and CHP 30.

Numerous studies have shown that enriching wheat bread with plant additives has a positive effect on its nutritional value [11]; hence, the contents of selected chemical components in both wheat flour and chickpea flour as well as the bread obtained from them were determined. The results are presented in Table 3.

Table 3. Chemical compositions of tested bread.

\begin{tabular}{|c|c|c|c|c|c|c|c|}
\hline \multirow{2}{*}{$\begin{array}{l}\text { Type of } \\
\text { Bread }\end{array}$} & \multirow{2}{*}{$\begin{array}{c}\text { Dry Matter } \\
(\%)\end{array}$} & \multirow{2}{*}{$\begin{array}{c}\text { Protein } \\
\left(\% \text { d.m. }{ }^{*}\right) \times 6.25\end{array}$} & \multirow[b]{2}{*}{ Fat (\% d.m.) } & \multirow{2}{*}{$\begin{array}{l}\text { Total Ash } \\
\text { (\% d.m.) }\end{array}$} & \multicolumn{3}{|c|}{ Dietary Fibre (\% d.m.) } \\
\hline & & & & & $\begin{array}{l}\text { Insoluble } \\
\text { Fraction }\end{array}$ & $\begin{array}{l}\text { Soluble } \\
\text { Fraction }\end{array}$ & Total \\
\hline \multirow{2}{*}{$\mathrm{CHP}$} & $90.56 c^{* *}$ & $16.50 \mathrm{a}$ & $1.57 \mathrm{a}$ & $2.75 \mathrm{a}$ & $2.49 \mathrm{a}$ & $1.30 \mathrm{a}$ & $3.79 \mathrm{a}$ \\
\hline & \pm 0.05 & \pm 0.04 & \pm 0.08 & \pm 0.09 & \pm 0.09 & \pm 0.01 & \pm 0.16 \\
\hline \multirow{2}{*}{ CHPC10 } & $90.54 \mathrm{c}$ & $18.06 \mathrm{~b}$ & $2.19 \mathrm{~b}$ & $3.28 c$ & $4.00 \mathrm{~b}$ & $1.87 \mathrm{~b}$ & $5.87 \mathrm{~b}$ \\
\hline & \pm 0.02 & \pm 0.02 & \pm 0.02 & \pm 0.08 & \pm 0.03 & \pm 0.09 & \pm 0.01 \\
\hline \multirow{2}{*}{ CHPC15 } & $89.03 \mathrm{~b}$ & $18.32 \mathrm{~b}$ & $2.46 \mathrm{c}$ & $2.93 \mathrm{~b}$ & $4.58 \mathrm{c}$ & $1.82 \mathrm{~b}$ & $6.40 \mathrm{c}$ \\
\hline & \pm 0.06 & \pm 0.04 & \pm 0.04 & \pm 0.07 & \pm 0.02 & \pm 0.03 & \pm 0.04 \\
\hline \multirow{2}{*}{ СНРC30 } & $89.57 \mathrm{a}$ & $19.64 \mathrm{c}$ & $2.58 \mathrm{~d}$ & $3.65 \mathrm{~d}$ & $6.03 \mathrm{~d}$ & $2.33 \mathrm{c}$ & $8.35 \mathrm{~d}$ \\
\hline & \pm 0.03 & \pm 0.01 & \pm 0.08 & \pm 0.04 & \pm 0.02 & \pm 0.06 & \pm 0.08 \\
\hline
\end{tabular}

*d.m. - dry matter; ${ }^{* *}$ Mean values in columns denoted by different letters differ statistically significantly at $p \leq 0.05$.

All the breads with chickpea flour showed a higher nutritional value than the wheat bread (Table 3). Even a 10\% share of this flour significantly influenced the contents of protein (1.5\% more), fat and ash (almost $1 \%$ more), as well as total fibre ( $2 \%$ more), compared to wheat bread (Table 3). The highest content of all the tested ingredients was found in the bread with a 30\% share of chickpea flour; however, it was rated the worst in terms of quality.

In the tested breads with chickpea flour, a significantly higher ash content was found, which mainly consists of minerals. Hence, the contents of selected micro- and macronutrients were also determined. The results are shown in Table 4.

Table 4. Contents of selected macro- and micronutrients.

\begin{tabular}{cccccccccc}
\hline \multirow{2}{*}{$\begin{array}{c}\text { Type of } \\
\text { Bread }\end{array}$} & \multicolumn{7}{c}{ Contents of Selected Macro- and Micronutrients (mg/kg d.m.) } \\
\cline { 2 - 10 } & $\mathbf{C a}$ & $\mathbf{K}$ & $\mathbf{M g}$ & $\mathbf{P}$ & $\mathbf{N a}$ & $\mathbf{F e}$ & $\mathbf{Z n}$ & $\mathbf{C u}$ & $\mathbf{M n}$ \\
\hline \multirow{2}{*}{$\mathrm{CHP}$} & $265.19 \mathrm{a} *$ & $2397.00 \mathrm{a}$ & $7.65 \mathrm{a}$ & $1617.27 \mathrm{a}$ & $8417.93 \mathrm{a}$ & $16.83 \mathrm{a}$ & $14.17 \mathrm{a}$ & $1.71 \mathrm{a}$ & $7.65 \mathrm{a}$ \\
& \pm 4.12 & \pm 72.75 & \pm 0.66 & \pm 163.8 & \pm 190.95 & \pm 0.46 & \pm 1.75 & \pm 0.07 & \pm 0.36 \\
\hline \multirow{2}{*}{$\mathrm{CHPC10}$} & $427.84 \mathrm{~b}$ & $3515.31 \mathrm{~b}$ & $459.68 \mathrm{~b}$ & $2096.28 \mathrm{~b}$ & $8246.98 \mathrm{~b}$ & $28.68 \mathrm{~b}$ & $15.76 \mathrm{~b}$ & $1.96 \mathrm{~b}$ & $12.05 \mathrm{~b}$ \\
& \pm 3.23 & \pm 43.11 & \pm 12.32 & \pm 32.87 & \pm 0.15 & \pm 0.17 & \pm 0.26 & \pm 0.03 & \pm 0.03 \\
\hline \multirow{2}{*}{$\mathrm{CHPC15}$} & $488.11 \mathrm{c}$ & $3647.80 \mathrm{c}$ & $506.44 \mathrm{c}$ & $2101.11 \mathrm{c}$ & $7515.72 \mathrm{c}$ & $31.35 \mathrm{c}$ & $16.11 \mathrm{c}$ & $2.19 \mathrm{c}$ & $13.26 \mathrm{c}$ \\
& \pm 5.78 & \pm 21.65 & \pm 12.41 & \pm 15.76 & \pm 0.00 & \pm 0.26 & \pm 1.05 & \pm 0.03 & \pm 0.03 \\
\hline \multirow{2}{*}{$\mathrm{CHPC30}$} & $516.30 \mathrm{~d}$ & $5149.88 \mathrm{~d}$ & $629.32 \mathrm{~d}$ & $2379.82 \mathrm{~d}$ & $8228.93 \mathrm{~d}$ & $72.11 \mathrm{~d}$ & $19.77 \mathrm{~d}$ & $3.24 \mathrm{~d}$ & $15.47 \mathrm{~d}$ \\
& \pm 10.41 & \pm 14.32 & \pm 15.32 & \pm 5.43 & \pm 0.09 & \pm 0.07 & \pm 0.14 & \pm 0.00 & \pm 0.01 \\
\hline
\end{tabular}

${ }^{*}$ Mean values in columns denoted by different letters differ statistically significantly at $p \leq 0.05$. 
In all the breads with chickpea flour, significantly higher contents of all the determined macro- and micronutrients were found (Table 4_). Particularly noteworthy is the increase in the content of iron ions (approx. $12 \%$ in the bread with a $10 \%$ share) and the increase in the content of manganese (approx. 5\%) compared to wheat bread (Table 4). The increase in the contents of $\mathrm{Mg}, \mathrm{Ca}$ and $\mathrm{P}$ in the tested wheat-chickpea bread is equally valuable. Even $10 \%$ chickpea flour increased the content of Ca by a half, Mg by 65 times, and $\mathrm{P}$ by 1.5 times, in relation to wheat bread (Table 4 ).

The glycaemic indices were also determined in the tested bread with an in vitro method. The results are presented in Table 5. All the breads with chickpea flour showed significantly lower in vitro glycaemic indices compared to the wheat bread. An inversely proportional relationship was found: the higher the proportion of chickpea flour, the lower the glycaemic indes IG (Table 5).

Table 5. Glycaemic index (IG) of tested bread.

\begin{tabular}{cc}
\hline Type of Bread & Glycaemic index IG (\%) \\
\hline CHP & $94.6 \mathrm{~d}^{*}$ \\
CHPC10 & $86.9 \mathrm{c}$ \\
CHPC15 & $80.3 \mathrm{~b}$ \\
CHPC30 & $74.9 \mathrm{a}$ \\
\hline
\end{tabular}

${ }^{*}$ Mean values in columns denoted by different letters differ statistically significantly at $p \leq 0.05$.

The favourable reduction in the glycaemic indices of the wheat-chickpea breads in relation to wheat bread was the result of a difference in their chemical compositions (Table 5). The higher contents of fat and dietary fibre had a significant impact. As shown in the studies of other authors, fatty compounds, in addition to protein and organic acids, create a physical barrier surrounding carbohydrates, thus reducing the rate of their decomposition and digestion, which reduces the glycaemic index of the product [12].

The significantly higher protein content noted in the wheat-chickpea breads probably decreased the glycaemic index, because protein reduces the glycaemic index by stimulating insulin secretion [12,13], as well as limiting the availability of starch for $\alpha$-amylase by "encapsulating" it in its structures [14].

It should be emphasized that eating more-dense bread results in a lower glycaemic response in the body. This bread stays longer in the digestive tract during the digestion process, and its particles are larger, so the surface area for alpha-amylase's action on the starch is reduced. As a result, starch hydrolysis is slower and the glycaemic index is lowered [14], which was confirmed by the research of this work.

\section{Conclusions}

The supplementation of wheat bread with chickpea flour resulted in a quality of the breads comparable to that of wheat bread, and at the same time, they had a much better chemical composition. In addition, significantly lower values of the glycaemic index for these breads were found in relation to wheat bread; therefore, chickpea flour should be considered a wholesome raw material in production.

Institutional Review Board Statement: The experiments conducted as part of the research did not require the approval of the Institutional Review Board at the time of their conduct.

Informed Consent Statement: Informed consent was obtained from all subjects involved in the study.

Data Availability Statement: Data available on request.

Acknowledgments: The research was financed from a grant awarded by the Ministry of Science and Higher Education for statutory activities.

Conflicts of Interest: The authors declare no conflict of interest. 


\section{References}

1. Jukanti, A.K.; Gaur, P.M.; Gowda, C.L.L.; Chibbar, R.N. Nutritional quality and health benefits of chickpea (Cicer arietinum L.): A review. Br. J. Nutr. 2012, 108, S11-S26, doi:10.1017/S0007114512000797.

2. Bampidis, V.A.; Christodoulou, V. Chickpeas (Cicer arietinum L.) in animal nutrition: A review. Anim. Feed Sci. Technol. 2011, 168, 1-20.

3. Biggs, M.; McVicar, J.; Flowerdew, B. Wielka Księga Warzyw, Ziót i Owoców; Wyd. Replika: Warszawa, Poland, 2007.

4. Molenda, J. Rośliny, Które Zmienity Świat; Wyd. Replika: Poznań, Poland, 2011.

5. PN-A-7418. Research Methods; BakeryPolski Komitet Normalizacyjny: Warszawa, Poland, 1996.

6. AOAC. Official Methods of Analysis, 18th ed.; Association of Analytical Chemists International: Gaithersburg, MD, USA, 2006.

7. Goni, I.; Garcia-Alonso, A.; Saura-Calixto, F. A starch hydrolysis procedur to estimate glycemic index. Nutr. Res. 1997, 17, 427437.

8. Czubaszek, A. Charakterystyka Technologiczna Mieszanek Mąki Pszennej z Produktami Przemiału Owsa; Zeszyty Naukowe Uniwersytetu Przyrodniczego we Wrocławiu, Wydawnictwo Uniwersytetu Przyrodniczego we Wrocławiu: Wrocław, Poland, 2008; Volume 564.

9. Gambuś, H.; Gambuś, F.; Pisulewska, E. Całoziarnowa mąka owsiana jako źródło składników dietetycznych w chlebach pszennych. Biuletyn IHAR 2006, 239, 259-267.

10. Sikorski, Z.E. Chemia Żywności. Odżywcze i Zdrowotne Właściwości Składników Odżywczych; Wydawnictwo Naukowo-Techniczne: Warszawa, Poland, 2007.

11. Dewettinck, K.; van Bockstaele, F.; Kuhne, B.; van de Walle, D.; Courtens, T.M.; Gellynck, X. Nutritional value of bread: Influence of processing, food interaction and consumer perception. J. Cereal Sci. 2008, 48, 243-257.

12. Englyst, K.N.; Englyst, H.N. Carbohydrate bioavailability. Br. J. Nutr. 2005, 94, 1-11.

13. Venn, B.J.; Green, T.J. Glycemic index and glycemic load: Measurement issues and their effect on diet-disease relationships. Eur. J. Clin. Nutr. 2007, 61 (Suppl. 1), S122-S131.

14. Fardet, A.; Leenhardt, F.; Lioger, D.; Remesy, C. Parameters controlling the glycaemic response to bread. Nutr. Res. Rev. 2006, 19, 18-25. 